\title{
The cry of earth and conflict with human cultures: a reflection for Christian religious educators
}

\author{
Miriam K. Martin ${ }^{1}$ iD
}

Published online: 2 July 2015

(C) The Author(s) 2015. This article is published with open access at Springerlink.com

\begin{abstract}
How can religious educators encourage a sacred, meaningful relationship between humanity and Nature? What contribution can religious educators make to a renewed understanding of what it means to be human? The author brings two propositions to the discussion: that this relationship is largely one of conflict, and that, although it has been rightfully critiqued, Christian teaching and theology can positively contribute to the solution of the conflict. In analyzing the conflict, Martin reflects on de Groot's and van den Born's metaphors for the human-nature relationship: Master, Steward, Partner and Participant. Martin disputes the views that a dichotomy exists between humanity and Nature and that humanity is superior, pointing to the more inclusive worldview offered by Berry and Russell, which favours the value of all of Creation. The author suggests lines along which answers may be sought: rethinking what it means to be human in relationship to Nature, and including in Religious Education the study of the origins of life, united to contemplation of the divine presence in Creation. This combination will lead to the transformation of consciousness that is crucial to a solution of the human versus Nature conflict. Martin raises pertinent questions concerning the emergence of life, the cosmos, and humanity, which may be summarized in her final questions regarding "who we are, whose we are and whom we are for".
\end{abstract}

Keywords The cry of earth · Conflict with cultures · Eco-theology $\cdot$ Christian religious education

Miriam K. Martin

mmartin@ustpaul.ca

1 Faculty of Human Sciences, Saint Paul University, Ottawa, Canada 


\section{Introduction}

This article entertains a fundamental question: Within their particular faith-based practises, how can religious educators respond credibly to the ecological and environmental crisis of our day? There are many articulations of the crisis and many possible approaches to pursue for adequate Christian responses. In this text, however, we will attempt to uncover what foundational thinking that undergirds the theological frameworks of the problem and to lay the groundwork for some possible solutions. To begin, we will examine the interconnection between underlying assumptions of culture and religion that hinder a positive response to the crisis as well as to highlight those that would assist in creating faith-filled responses. We will then explore a more inclusive and connected view of human-earth relationships offered by Peter Russell and Thomas Berry. This will lead us to reflect on alternative descriptive metaphors that may expand our understanding of that relationship. We will conclude with eco-theologian Heather Eaton's challenge to educators and with some responses from religious education that describe the task for future work in the field.

\section{Culture, religion and human conflict with nature}

A basic understanding of culture describes the ways by which values and human traditions are developed, safeguarded, celebrated and transmitted for the next generations. The most deeply held philosophies of what it means to be human are contained within cultural practices. In North America, we often speak in grandiose terms of what we describe as our version of Western culture. We name its authorities and characteristics in the history of art, science, and literature and in all aspects of life that we have come to treasure. The broad strokes of what make up this great Western dream of life are indicated by our politics, our policies, our education and health care systems, our way of keeping law and order, and our religious traditions. Yet, other voices have arrived to challenge these views. Some of them can be found in eco-theology and religious education.

This article focuses on the relationship between human beings and nature in a Canadian cultural context, and reflects on the place of religious education within it. Given the ecological health of the planet and the tragedies of environmental degradation, the discussion is framed to consider how we as religious educators may find ways to respond credibly from our faith education perspective. ${ }^{1}$ To continue this discussion, I would like to offer two propositions to help frame the conversation.

The first proposition is that there are conflicts taking place between human and other living beings in the Earth community. Even the way we name the actors of this conflict is telling. We fumble for adequate descriptors. What name should we give to that which is "other"? Nature? The natural world? The environment? The earth community? All these titles have their own histories and connotations that present difficulties worth exploring elsewhere; the challenge that this choice of words presents is nevertheless worth mentioning here.

However we designate it, this conflict happens between the human and the rest of nature in the micro systems of local bio-regions, where air, water, plant, bird and animal life are being systematically or haphazardly marginalized or eliminated. It occurs in macro systems such as the hydrosphere (water), the atmosphere (air) and the biosphere, and is evidenced

${ }^{1}$ See the United Nations website on the environmental situation updated regularly, http://unstats.un.org/ unsd/environment/default.htmh. 
in the growing spectre of global climate change. The ongoing discussion of these matters by the United Nations and its charge to governments to halt environmental degradation are indicative of the global extent of the conflicts. Despite all warnings, humans continue to engage in destructive behaviours that threaten the integrity of these systems (United Nations 2013).

For example, Canadians are in the midst of an intense and protracted debate over the development of the Northern Gateway Pipeline that would bring oil from the province of Alberta through to the coast of British Columbia. It is a project that highlights the conflict of values among many constituencies regarding economic development, job creation, the integrity of living creatures, and the preservation of lands and the rights of First Nations Peoples (Government of Canada 2014). This ongoing debate reveals that, while Canadian culture is being driven by the ideals and meanings made in our consumer culture, we are endangering life around us. In the midst of pursuing a dream of well-being that is linked to our present vision of human flourishing, we are willing to sacrifice the ecological integrity of the very Earth that sustains us. Canadian scientist and journalist David Suzuki makes it clear that this thinking is untenable; it is impossible to think of a sustainable ecology and sustainable human life when the unfettered drive for profit rules the political decisions of our day (Suzuki and Dressel 2004).

The conflict of our cultural values and the ecological integrity of Earth confronts us as religious educators who are engaged in the formative and transformative aspects of educating religiously toward a fullness of life for all.

Thus follows my second proposition: that our Christian religious tradition and our theological discourse have something important to contribute in this situation of human conflict with the rest of nature. But this has not always nor universally been accepted. From the time Lynn White argued that Christianity was a major contributor to the present ecological crisis (White 1974), theologians and philosophers have critiqued the role that Christianity has played in human exploitation of nature. ${ }^{2}$ Two major connections that have been presented in the debate regarding Christianity's impact on environmental degradation are relevant for our discussion here. The first is that Western culture's pervasive attitude is to maintain control and mastery over nature, and the second is that Christianity provides a solid foundation for this dominating stance (de Groot and van den Born 2007). As religious educators, our ability to enter this debate in a vital manner depends on our theological knowledge, experience and resources, our educational praxis and our understanding of the relationship between religion and culture.

\subsection{Culture and religion}

Clifford Geertz's seminal article, "Religion as a Cultural System" (Greetz 1974), and the variety of commentaries and discussions that followed its publication have designated religion to be a central aspect of cultural analysis. Geertz defines culture as "an historically transmitted pattern of meaning embodied in symbols, a system of inherited concepts expressed in symbolic forms by means of which men (sic) communicate, perpetuate, and develop their knowledge about and attitudes toward life" (Geertz 1973, p. 89). Geertz's description is relevant for religious educators, as evidenced by Maria Harris and Gabriel Moran, who state that, not only are we involved in teaching about a religious way of life, we must also teach and model the living of that way (Harris and Moran 1998). This dual

${ }^{2}$ For a summary discussion of this tension see: Roger Gottlieb, The Oxford Handbook of Religion and Ecology (Oxford Press 2006), "Introduction”, pp. 1-13. 
approach addresses the heart of our dilemma as our understanding about ecological devastation grows while our response remains inadequate.

When considering the clash between human beings and other "createds" (a term used by First Nations storytellers), I find Geertz's definition of religion to be helpful. According to him, "religion tunes human actions to envisioned cosmic order and projects images of cosmic order onto the plane of human experience" (Geertz 1973, p. 90). In terms of religion, Western religious culture has often been contrasted with Eastern religions and Eastern cultures. However, with the global consciousness made possible in our postmodern dynamic of dramatic, immediate communication, seemingly distinct cultures are encountering each other, and some blurring of the self-described boundaries is occurring.

To add further complexity to the situation, our North American view of Western culture does not contain a unified outlook; rather, we experience many divisions, many differing cultures across the continent. Certainly, there are an American (United States) version and a Canadian version of cultural identification, but these often ignore or are ignorant of less dominant cultures that make up this geographic region. What of our First Nations peoples and the impact of the growing Eastern and African immigrant populations? How does Mexico factor into our North American cultural identity?

Looking more closely at the cultural dynamic within the national boundaries of Canada, we discover significant differences among the geographical, ethic, linguistic and religious backgrounds of the people who live here. Canada expresses its cultural phenomenon as a mosaic (Gibbons 1938), a metaphor that suggests one nation made up of very different colours and textures that are all held in a single frame. On one hand, this provides strength in terms of regions and a multicultural identity; on the other hand, it opens the way for withdrawal into a parochial regionalism or into ghettoized communities. This loose sense of nationalism, then, represents opportunities for diversity while adding challenges for unity.

However, the issues of global warming and transnational biocide that were mentioned in the introduction of this paper require a larger view, one that extends beyond our national, political, religious, ethnic, racial, generational and economic divisions. From the various cultural standpoints and worldviews that humans embrace, a plethora of approaches and visions for a faith response to the ecological crisis are possible. From my perspective, I believe that a larger, more connected and comprehensive vision of nature and Earth are required for the health and vitality of Earth and all living beings. In this regard, I have found that the work of Peter Russell and Thomas Berry offer a strong and compelling perspective to consider.

\subsection{A more connected and inclusive vision: Peter Russell and Thomas Berry}

Can we imagine Earth holding within itself an energy that is moving toward great complexity, meta-narratives, laws and deep principles, teachings, and art forms that provide an integral system, of life forces that are often in conflict with the dominant human cultures? The work of Peter Russell and Thomas Berry suggests that there is this greater, more inclusive communion that lies beneath and within all others, the living Earth in the midst of an expanding Universe.

Peter Russell relates his own path to a larger, more connected vision of reality and its implications for Earth-Human relationships (Russell 2006). In his introduction to From Science to God, Russell ties the great religious traditions and their teachings to a larger and more connected vision of reality. He recalls his experience of re-encountering the Sacred through and beyond his studies of science. He describes the book as "a journey of ideas 
that starts with science and arrives at God; it is also my own personal journey from a physicist with little interest in spiritual matters to an explorer of consciousness who now begins to appreciate what the great spiritual teachings have been trying to show us for thousands of years" (Russell 2006, p. 3).

In his books and educational videos, "The Global Brain" and "The White Hole in Time", Russell traces the emergence of life on the planet using the metaphor of communication to make the scientific story of evolution accessible. He describes the processes by which earliest cell formations exchanged vital information. Soon communication crossed through into multi-cellular conversations. The complexity of life was deepened as information was shared and more and more complex life forms emerged. With the emergence of sexual reproduction, quantum leaps happened in the evolutionary process of this cellular information sharing. In sexual reproduction, two cells came together, shared their inherited genetic information and produced offspring that possessed a combination of their genes. No longer did it take thousands of generations for just one genetic difference to arise. Differences now occurred in every generation, speeding the rate of arrival of novelty a thousand-fold (Russell 1998). In this process, life forms share their genetic codes and their very DNA. Russell describes these intricate processes of evolution leading to the development of the human brain and the emergence of human consciousness. The rapidity of the change in communication across the planet is woven into one great image that he calls the Global Brain. ${ }^{3}$ Each thing and everything is in relationship, in communication with each other thing.

This idea of interrelationship is developed in another way in the work of Thomas Berry, who says that each organism represents itself to every other organism in one whole community of interconnection (Berry 1999).

Berry's study of culture and global anthropology in a religious context led him to some startling realizations. His inclusive, cosmic-sized analysis challenges the often-troublesome terms used to divide and compartmentalize the world of culture differences and their consequent valuing. Consider the vision Berry puts forward in The Great Work:

In reality there is a single integral community of the Earth that includes all its component members whether human or other than human. In this community, every being has its own role to fulfill, its own dignity, its inner spontaneity. Every being has its own voice. ...This capacity for relatedness, for presence to other beings, for spontaneity in action, is a capacity possessed by every mode of being throughout the entire universe. (Berry 1999, p. 4)

This vision is reiterated in a provocative image offered by Brian Swimme: "The Earth was once a molten mass and now sings opera".

The communication and inter-relationality that have been described above challenge a way of thinking that divides human beings from one another, human beings from nature, and the rest of the living Earth from human communities. This cosmic Earth view has particular consequences for developing ethical behaviours, for establishing relational modalities, and, indeed, for renewing religious teaching and practices. As human beings in the great web of life of this cosmic Earth system, we stand in a place of mutuality that requires humility and a destabilizing of our anthropocentric attitudes and action. Berry suggests all beings have the right to be recognized as having their own integrity and, as

\footnotetext{
3 The video presentation is quite captivating as colour and animation intensify the experience of the connections and the rapidity of growth. For complete video see: http://www.peterrussell.com/GB/ globalbrain.php.
} 
with human rights, as having certain limits. Berry argues that we need to find a new way of being and affirming who we are with the rest of the natural world.

We have no right to disturb the basic functioning of the bio systems of the planet. We cannot own the Earth or any part of the Earth in any absolute manner. We own property in accord with the well-being of the property and for the benefit of the larger community as well as ourselves. (Berry 1999, p. 5)

What is perhaps most challenging in this analysis is the manner in which Berry situates the human system as a subsystem of the Earth. He suggests that it is the whole community of living species-which includes the human - that has the greater value, and this must be our primary concern, even if we only consider our own human survival (Berry 1999). In this way, he confronts the understanding of our dominant rather than our unique place in creation.

Within the emerging universe story, we ask, "What does it mean to be human?" What follows for us as religious educators is the question, What kind of Christian religious education do we need in order to meet Earth with ecological integrity and to strive towards the fullness of the Christian gospel vision of the fullness of life for all? How might a Christian religious educator respond to the call to reimagine what it means to be human within the visions of one comprehensive Earth community?

\section{The emerging universe and what it means to be human}

A fresh articulation of what it means to be human is required if we are to respond to Berry's vision of a variegated, single Earth community and to Russell's image of the interconnectedness of life on Earth. Both science and religion are re-visioning the relationship between the human and the other-than-human world. The amazing history of the universe, to which current generations have unique access, has changed the manner in which both of these disciplines pursue truth and meaning, particularly in regards to life on planet Earth. ${ }^{4}$

In the more recent past, the views of science and religion have been contradictory, or at least, at times oppositional. This conflict diminishes when goals and interests are shared. David Suzuki expresses it this way: "Theologians and ecologists are finding common ground as they explore the need to recognize the sacred in the here-and-now, rather than in the hereafter, and trying to help human beings return home to their place in creation" (Suzuki et al. 2007, p. 280). What is our place in the world, in the cosmos? How do we name who we are in this vast new cosmogenesis, in this privileged place where we as humans can look back, begin to imagine the very beginnings of life and dream anew of its future?

The "New Universe Story", or the "Emerging Universe Story", is not new of course, but rather so ancient that it is almost beyond our comprehension; the dynamics of life emerging and the ongoing evolutionary processes continue to be breath-taking. ${ }^{5}$ Awe and

\footnotetext{
${ }^{4}$ It still surprises me that, in spite of all the space exploration, the marvelous photographs that show Earth nested in space, galaxies and images more startling than science fiction, we still hold on to a more fixed, up/down vision of reality that has implications for our faith, our religious practice regarding this world and our thoughts about the next.

${ }^{5}$ For example, see: Berry and Swimme, The Universe Story (San Francisco: Harper 1992); Wessels 2003). Also see: Carole Martignacco, The Everything Seed (Minnesota: Beavers Pond Press, 2003); Peter Russell, A White Hole in Time. DVD Production (a children's story).
} 
wonder are appropriate responses to the stunning mysteries of this powerful story in which science and theology meet once again to ponder the deep questions: How did life begin? What are the origins of humanity? Who is the author of this grand drama? Does life have a purpose? Are there overarching principles that guide life's unfolding?

Too often, the starting point for reflection on the cosmos begins simply with human emergence, and its ultimate goal seems to be human dominance and superiority. As previously mentioned, Christianity has often been blamed for continuing this perspective of human dominance and for being a primary contributor to seeing humans as separate from the rest of the natural world. However, modern science has also contributed to the detrimental understanding of the divide between human beings and nature. Elspeth Whitney, reflecting on the evolving conversation between religion and science, concludes that, as the view of a mechanized world became increasingly dominant in the early modern era, scientists set nature apart as a thoroughly impersonal and "other" realm to be approached, not by building rapport through sympathetic insight but by manipulation through experiment (Whitney 2002).

Currently, some scientific and religious reflections are developing a focus that is more consistent with a connected, inclusive vision of reality. In this regard, Sallie McFague, speaking from a theological perspective, suggests holding our stories together in a wider, more comprehensive way:

It is a cosmological, evolutionary, ecological story; that is, it includes everything that is; it claims everything has evolved from the tiny exploding matter billions of years ago; and it implies, therefore that all things are interrelated and interdependent in both micro and macro ways... We are part and parcel of all that has gone before us; they are our ancestors, our kin, and our roots. (McFague 2008, p. 46)

What is required, then, is a more constructive way to speak about the human in relation to the rest of creation. To begin, we may need to reinterpret or move beyond some of the traditional interpretations of the biblical metaphors in order to imagine new ways of describing ourselves in relationship with the rest of creation.

\section{Extended metaphors for earth-human relationship}

In a study exploring the interrelationships between humans, nature and God, de Groot and van den Born determine four basic classifications to describe the relationship between humans and nature: Master, Steward, Partner and Participant. Two of these are familiar in Christian circles: in a brief but comprehensive review of Roman Catholic documents regarding human relationships with creation, the metaphors that appear most consistently are "master" and "steward" (Hart 2004). The four classifications are not intended to be held in isolation, but the ideas that they communicate are offered to deepen and clarify our theological anthropologies (de Groot and van den Born 2007).

The first classification they propose is the notion of human beings as Masters over creation. In the Judeo-Christian context, this notion often seems to come from a particular reading of the first creation narrative of Genesis, in which human beings are created to "have dominion over" the rest of creation (Genesis 1:26-28). This sense of detachment from Earth and Earth's creatures is also echoed by the early modern scientific revolution that saw mastery over nature as its imperative. In other words, to insure human progress and the development of human culture, human beings can, with impunity, do whatever they will with the "stuff" of Earth. 
The second classification suggested by de Groot and van den Born describes the idea of human beings as Stewards. This places the human above nature, though in a more benign way; the notion is tempered somewhat by the hierarchical understanding that, although humans are above nature, God is above the human. Nature is seen as the great gift of God to humans, and humanity has a responsibility to look after it appropriately, whether for God or for future generations. This echoes the work of Hart (2004), who suggests that perhaps this metaphor is the dominant one found in Roman Catholic Church documents on the environment. A letter from the Canadian Bishops (2008) gives a clear indication of a preference for this model:

On this minuscule planet, a human being is created in the image and likeness of God: capable like God, of knowing, loving and acting freely and responsibly.... The Earth is entrusted to humanity like a garden that is managed but not owned. (CCCB 2008, p. 2)

The relationship of human to Earth described here is definitely more gracious than that of the Master, since the idea of stewardship entails a real sense of care and concern. The gift of God is incredible in its beauty and vastness, and it requires a commensurate responsibility.

In the third classification, Partner, the human stands side by side in partnership with nature. This includes an important shift from the Steward metaphor, for here nature has its own status and independent value. Humans and nature work together in a dynamic process of interaction and mutual development, demonstrating a sense of equity or balance of power between them (de Groot and van den Born 2007). Their analysis also revealed that this category occasionally posed problems for some participants in the study. Some people found it more difficult to relate to this Partnership model, saying it was ambiguous, and that it left them with more questions than answers. They wondered if it is possible for humans to communicate reasonably with nature and to assist in fulfilling nature's goals. Can having goals even apply to nature: is it not a human concept indicating a certain anthropomorphism (de Groot and van den Born 2007)?

The intrinsic value and distinctiveness of nature is a concept that Roman Catholic Church documents seem to approach with caution. Pope Benedict XVI highlights this, for example, in a stirring message on the World Day for Peace in 2010. Concurrent with an apparent movement towards a Partnering model, corresponding tensions arise when it seems that those who are concerned about the well-being of the whole planet might somehow diminish or challenge the dominant Church view of the human in creation:

If the Church's magisterium expresses grave misgivings about notions of the environment inspired by ecocentrism and biocentrism, it is because such notions eliminate the difference of identity and worth between the human person and other living things. In the name of a supposedly egalitarian vision of the "dignity" of all living creatures, such notions end up abolishing the distinctiveness and superior role of human beings. (Benedict XVI 2010)

The pressing issue here seems to lie in our self-understanding, our operative anthropology. Why must recognizing difference include the insistence on a dominance that reflects a hierarchal, separational worldview rather than a vision of inter-connectedness and communion? Why must our self-understanding insist on a superior positioning rather than on a unique or distinctive role in the dynamic unfolding of the universe?

De Groot and van den Born suggest a fourth metaphor: the human as Participants. Here the separation from nature specified by the other classifications is collapsed, for, as 
Participants, humans are an integral part of nature, not only biologically but also spiritually, and this relationship is a central aspect of human identity. Although all respondents in the study who chose the Participant category affirmed the aspect of humans being an integral part of nature, many of them had difficulty relating to the idea of a spiritual connection between nature and humans (de Groot and van den Born 2007). The Indigenous and Buddhist respondents gravitated most to the Participant model. Indigenous persons suggested that this was the model they had been taught, and the spiritual connection in particular best described their traditional way of thinking about the relationships between humans and other createds (de Groot and van den Born 2007). Nevertheless, classifying humans as Participants challenges traditional Christian anthropology, as is evident in the previously cited letter from Pope Benedict, in which he insists on the separate and superior role of humans (Benedict XVI 2010).

What does it mean when-even if they are to be shared-the blessings of creation are seen simply as distributable goods, a view reflected in these statements: "God has destined the earth and everything it contains for all peoples and nations. The goods of creation belong to humanity as a whole" (Benedict XVI 2010). How will such an anthropological position encourage human beings to recognize the interconnectedness of all life and to appreciate the deepest gifts of diversity, the distinctive and the different as delightful, true gifts of God to be treasured and celebrated? I propose that we need to rethink an anthropology that unnecessarily threatens the rest of creation, and here I refer to human threats rather than other conflicts that occur in the rest of nature. How do we resolve the opposition between humans and nature, the goodness of all creation and the fracture in the integrity of the Earth community wrought by human purpose and design? What is the cause of the threat to our humanity and to our religious beliefs that is insinuated here? Somehow, the respect and care for Earth and for the flourishing of humanity need to be held together.

Pope Francis articulated this challenge in his first words to the world community: "Let us be protectors of creation, protectors of God's plan inscribed in nature, protectors of one another and of the environment" (Winfield 2013). Pope Francis holds together the plea for the integrity of the Earth and justice for those made poor, offering both a fresh hope and a serious push back to our customary ways of thinking about ourselves as human beings and the rest of creation. Given the difficulties we have describing ourselves in relationship to the rest of the natural world and our seemingly limited view of the cosmos, we must try to reimagine those relationships and to take inspiration from the vision of the Partner and Participant described in the de Groot study. It is confounding for us to speak of "Nature", "the natural world", "creation", and "the environment" as if we are not somehow an integral and intimate part of it.

\section{Concluding responses from eco-theology and religious education}

Eco-theologian Heather Eaton insists that, in spite of the difficulties and challenges involved, we must continue to speak about those relationships and to explore evolutionary thinking in our theological research. Eaton insists on the critical study of evolution in order to understand and appropriate a workable theological worldview.

To integrate the reality of evolution situates us in the process, countering the emphasis on radical human/nature difference. To appreciate evolution is to appreciate the human bond, indeed human intimacy, with the natural world. This gives 
insight into evaluating the adequacy of responses to ecological issues. Evolution contributes to a new world view. (Eaton 2007, p. 22)

For her, the integration of religion and religious thought in an evolutionary framework is essential if religion is to have any real impact on the ecological conversation and if we are to share in faithful living that works towards the health of the whole planet. It is also obvious in this vein that religious practice and research, integral aspects of religious education, are also important to the work of ecological integrity. Eaton elaborates by emphasizing the vital part that religions can play as an evolutionary aspect of human consciousness. Religious knowing, then, is as important and as valid as scientific knowing.

The direction for engagement is clear for religious educators as "religions must address the larger contexts and sources of human life, and thus understand something of evolution as well as religious consciousness (Eaton 2007, p. 27). Eaton has presented a task for us as religious educators to become familiar with aspects of evolutionary theory, and to engage in a focused effort to study and understand central aspects of current scientific exploration into the origins of life. This work can be a daunting interdisciplinary leap for many; yet numerous scholars have taken up the task of exploring the religious dimensions of the Emergent Universe Story. Some fine examples of such authors whose writings can be helpful for religious educators include Judy Cannato, Ilia Delio, Elizabeth Johnston, Diarmuid O’Murchu, Sandra Schneiders and Cletus Wessels.

So it can be seen that there are many places where we can begin to frame coherent responses to these deep questions of the meaning and the purpose of human life with the well-being of the whole Earth. How do we as religious educators continue to live out of the message of the gospel in our complex world with its competing values and demands for attention and loyalty? How do we contribute to a renewed understanding of what it means to be human in cultures that do not easily make the connection between the evolving and flourishing of life on Earth and the development and well-being of human beings?

From my own experience, as a religious educator and as a person seeking to continue to grow in faith, I find that it is often difficult to live and celebrate the wonder of God's unfolding story and the interconnectedness of all of life. I acknowledge my limitations-of language, knowledge, understanding, biases, time, capabilities, inabilities and shortcomings. I face the limitations of our collective cultural vision, educational frameworks, biases and oppressive values and economically driven politics. I regret the lack of deep conversation with colleagues in religious education for whom this work is also a passion. Few scholars in religious education are researching and writing from this perspective, although attention in theological circles is certainly growing exponentially. In 2000, Chamberlain pointed to this lacuna in North America (Chamberlain 2000). Since that time, some work has been done in the area; a few articles have been published in journals, though seemingly without contributing major texts. Within associations, interest groups in ecology and religious education come and go. Encouragingly, a web search of courses and syllabi in religious education and pastoral ministry reflect that the question is being addressed in some instances with more or less focus. Still, a gap remains between our appreciation of the reality of ecological devastation and our work in religious education toward changing the way we think and live.

Closing the gap requires study and research; the sources listed here and the authors that they engage point to various others who are also concerned with the conflicts among human-Earth relations. They indicate starting points. However, in order to truly appreciate 
and integrate the impact of the Emerging Universe Story within our research and to live out of a more connected vision of life, it also means taking the time and opportunity for deeper contemplative practices. This means giving conscious space to embrace and celebrate the Divine presence in all creation. It is important to place oneself in optimum situations to learn directly from the beauty and graces of God expressed in the Earth. For example, attending to the sacred mystery seasonally unfolding in the cycles of life-flourishing, diminishing, death and new life-gives fresh insight into the great paschal mystery of Christ while communicating healthy humility regarding who we are as human beings. Retreat and spiritual experiences offered by women religious and their associates have frequently led the way in this regard, as they have integrated this knowledge within their prayer, rituals and lifestyles (Taylor 2009). I have found that introducing students to these experiences and joining with experts from other fields in the natural sciences are also ways of expanding our human connection to the rest of the natural world (Martin 2010). This contemplative stance that leads to action reflects a certain kind of knowing: the kind that Parker Palmer refers to when he speaks of our knowing becoming an ethic (Palmer 2001), or the experience of knowing when knowledge gives way to wisdom (Martin and De Pison 2008) or the knowing, being and doing that reflect a change in consciousness that is lived out in practice. Engaging in contemplative practices within the course work itself can lead to deep knowing, which can challenge and change worldviews (Martin 2010).

Changing conflictual and disconnected worldviews requires a change of consciousness. The transformation of consciousness is a crucial step in responding to the ecological crisis, which is indeed a religious crisis, one in which education in faith is called to play a critical role. It is incumbent, then, on religious educators, both for ourselves and for our students, to find ways to engage the discourse of eco-theology and to place it centrally within the curriculum of religious education rather than on a list of "special topics".

Perhaps this paper has elicited more questions than answers. Yet, even in pondering the questions, there are clues and directions here for further work. Whatever our cultural context regarding this growing concern for ecological integrity, we might ask ourselves as religious educators: How can we respond creatively and effectively to the connected cries of the earth and those made poor (Boff 1997)? How can we attend with greater integrity to the conflicts between the human and the living Earth community of which we are a part? What are the critical ecological issues in our particular context, and what are the most appropriate moral and theological responses? How can we think, teach and act into a more dynamic and connected understanding of who we are and what we are?

Can we re-engage with the intimacies of the cosmos, fall in love again with creation, and know ourselves to be kin, to be intimately connected? How can we share this experience with the students who walk with us? Along with becoming informed by research, reading and consulting knowledgeable experts in ecology and theology, we need to inform our teaching towards a more contemplative and connected vision of the whole. Perhaps we might begin by making more time to be, to pray and to pay attention, knowing it is crucial that we learn afresh who we are, whose we are and whom we are for.

In the story of the universe God's mysteries unfold.

In the story of the universe, the great stories are told.

In the story of the universe, creation takes its place.

In the story of the universe we know abundant grace (Martin 2006). 
Open Access This article is distributed under the terms of the Creative Commons Attribution 4.0 International License (http://creativecommons.org/licenses/by/4.0/), which permits unrestricted use, distribution, and reproduction in any medium, provided you give appropriate credit to the original author(s) and the source, provide a link to the Creative Commons license, and indicate if changes were made.

\section{References}

Benedict XVI, (2010). "If you want to cultivate peace, protect creation." Message of His Holiness Pope Benedict XVI for the Celebration of the World Day of Peace, 1 January 2010.

Berry, T. (1999). The great work. New York: Bell Tower.

Boff, L. (1997). The cry of the earth, the cry of the poor. Maryknoll, N.Y.: Orbis Books.

Canadian Conference of Catholic Bishops. (2008). Our relationship with the environment. The need for conversion. Ottawa, ON: CCCB.

De Groot, M., \& Van den Born, R. (2007). Humans, nature and god: exploring their interrelationships in Victoria, Canada. World Views: Global Religions, Culture, and Ecology, 11(1), 324-351.

Eaton, H. (2007). The revolution of evolution. Worldviews: Global Religions, Culture, and Ecology, 11(1), 6-31.

Geertz, C. (1973). Interpretation of cultures: Selected essays by C. Geertz. New York: Basic Books.

Gibbons, J. (1938). Canadian mosaic. The making of a Northern Nation. Toronto: McClelland and Stewart.

Government of Canada. (2014). "Government of Canada Accepts Recommendation to Impose 209 Conditions on Northern Gateway Proposal”. Accessed June 20, 2014 from http://news.gc.ca/web/articleen.do?mthd=index \&crtr.page $=1 \&$ nid $=858469$.

Harris, M., \& Moran, G. (1998). Reshaping religious education: Conversations on contemporary practice. Louisville, KY: Westminster John Knox Press.

Hart, J. (2004). What are they saying about environmental theology?. N.Y.: Paulist.

Martin, M. K. (2006). A new dreaming: Sound recording of original music. St. John's: Conception Studios.

Martin, M. (2010). Religious education and new earth consciousness: Let us play. Theoforum, 41(1), 93-112.

Martin, M., \& De Pison, R. M. (2008). From knowledge to wisdom. Journal of Religious Education, 100(2), 157-173.

McFague, S. (2008). A new climate for theology. Minnesota: Fortress Press.

Palmer, P. (2001). The violence in higher education. Transcript of the public lecture by Parker Palmer given on November 29, 2001 at Wisconsin Union Theater, UW-Madison campus.

Russell, P. (1998). Waking up on time. Mt. Shasta, CA: Origin Press.

Russell, P. (2006). From science to god. CITY: New World Library.

Suzuki, D., \& Dressel, H. (2004). From naked ape to superspecies: Humanity and the global eco-crisis. Toronto: Greystone Publishing.

Suzuki, D., McCormick, D., \& Mason, H. (2007). The sacred balance. Rediscovering our place in nature. Toronto: Greystone Publishing.

United Nations IPCC Intergovernmental Panel on Climate Change. (2013). Climate change 2013: The physical science. Accessed May 28, 2014 from https://www.ipcc.ch/report/ar5/wg1/.

Wessels, C. (2003). Jesus in the new universe story. Maryknoll, N.Y.: Orbis Books.

White, L. (1974). "The historical roots of our ecologic crisis [with discussion of St Francis; reprint, 1967]," Ecology and religion in history. New York: Harper and Row

Whitney, E. (2002). Christianity and changing concepts of nature: An historical perspective. In D. Lodge \& C. Hamelin (Eds.), Religion and the new ecology (pp. 34-38). Notre Dame, Indiana: University of Notre Dame Press.

Winfield, N. (2013). Pope Francis: Protect the poor and the earth, Yahoo News, March 19, 2003. http://news. yahoo.com/pope-francis-protect-poor-earth-233743125.html. Accessed April 10, 2013 